\title{
$\mathrm{B} 101$ 軟弱地盤上における低圧車輪のけん引カ評価
}

\section{Drawbar Pull Evaluation of Low-Pressure Wheel on Deformable Terrain}

\author{
○正 成田 伸一郎, 正 大槻 真嗣, 若林幸子, 正 西田 信一郎 (JAXA/JSPEC)
}

Shin-ichiro NARITA, Masatsugu OTSUKI, Sachiko WAKABAYASHI, Shin-ichiro NISHIDA

JAXA/Lunar and Planetary Exploration Program Group, 3-1-1, Yoshinodai, Chuo-ku, Sagamihara, Kanagawa, 252-5210

\begin{abstract}
JAXA is developing a mobile rover to lunar surface exploration or base construction as a follow-on KAGUYA. Because the lunar surface is covered by regolith, implying an irregular and rough terrain, the rover has difficulty in mobility. Therefore a new low-pressure wheel is recommended for high mobility performance and low power consumption. A low-pressure wheel can change its contact shape and pressure distribution to account for terrain. In this paper, the procedure for the evaluation of drawbar pull calculated by shear stress on the deformable terrain is presented. This procedure is valuable for analyzing the interaction between a low-pressure wheel and the deformable terrain.
\end{abstract}

Key Words: Lunar Exploration Rover, Low-Pressure Wheel, Normal Stress Measurement, Drawbar Pull.

\section{1. 耤寻}

「かぐや」に続く月探查として，月面探査に向けた月着陸 探查の検討が進められている[1]. 月面上はレゴリスと呼ばれ る軟弱地盤で覆われていることが良く知られている。これに 加えて将来の拠点構筑ミッションでは, 極域やクレータ内域 等が探査対象であり，こうした場合は急勾配の傾斜面や切り 立った崖など比較的剛性の高い不整地面を走行しなけれぼ ならない可能性も高い. 探査ローバはこうした環境下でミッ ションを確実に達成するために, 不整地形状に合わせて接地 面積を拡大し, 進行方向への推進力となる路面之の摩擦力を 確保する走行系を備える必要がある[2]. 図 1 に月面探查ロー バの想像図を示す.

月面上は高真空, 放射線, 日照・日陰時の温度差が大きい, といった極限環境であり, 確実な走行を実現する走行機構の 検討が進められている[3]. 月面上の不整地に代表されるよう な軟弱地盤に対して車輪の走行性能評価を行うためには, そ の特性を把握することが必要であり，車輪のモデル化や軟弱 地盤上での検討が進められている[4]. 低圧車輪では弾性ばね を転動中心から車輪の半径方向に一様に配置した弾性車輪 の原理的試作車輪において検討がある[5].この車輪は転動時 の回転トルク伝達特性が低いことや, 月面上の $1 / 6[\mathrm{G}]$ 重力環 境では接地面圧力が小さくなり, 路面への力伝達に伴う非線 形な大変形特性を有することが課題である. また, 微小重力 環境を考虑した接地面圧力の計測や，その特性を試験・評価 する必要がある。

著者等は月面探査ローバの低圧車輪における性能評価を 行うことを目的として, 低圧車輪の特性計測技術の開発とモ デル化手法の確立を行っている. 低圧車輪の例として, これ までに原理的試作車輪の回転トルク伝達特性を改善するよ うに，車輪中央に剛体リムを置きこここから半径方向に弾性 ばねを配置した弾性車輪を試作した。また,この車輪が軟弱 地盤上を走行する際の接地面圧計測装置を開発し, 剛性車輪 と低圧車輪の $2 つ の$ 車輪について実際に計測を行い, テラメ カニクスから軟弱地盤上における低圧車輪の走行モデルを 構築し, 比較検討を行った[6]. また動力学解析ツールの開発 を行い，非線形特性を有する低圧車輪の走行性能評価を行っ ている[7].これに続き本研究では車輪が軟弱地盤上を走行す る際の垂直応力の解析・計測結果からせん断応力を算出し, 駆動力の評価を行った. 本稿ではこの評価結果について報告 する.

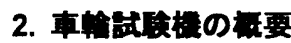

2-1 車輪支持台および車輪駆動装置

試作車輪を用いた走行試験の実験図を以下の図 2 に示す. 試験機は試作車輪駆動用のアクチュエータ, 車輪自重キャン セル機構, 走行方向と垂直に車輪に負荷を与える荷重機構, および剛性地盤で構成される. 車輪駆動用アクチュエータは 外部にモータドライバとコントローラを持ち, ロータリエン コーダの回転情報により任意の速度に制御可能である.また， 実験機には剛性地盤上に圧力センサが取り付けられており， その上を車輪が走行する際に接地面圧力とその圧力分布を 求めることが可能である. 車輪の特性パラメタと荷重, およ び走行条件は解析時と同一值で構成されている.

\section{2-2 試作車輪}

本試験機で車輪特性を検出する試作車輪の主仕様を表 1 に 示す. この試作車輪は金属低圧走行機構の例として作成した. 車輪は主に 3 つの部分から構成される. 中央に剛体リムを置 き,ここから半径方向に弾性板ばねを等間隔に配置する，板

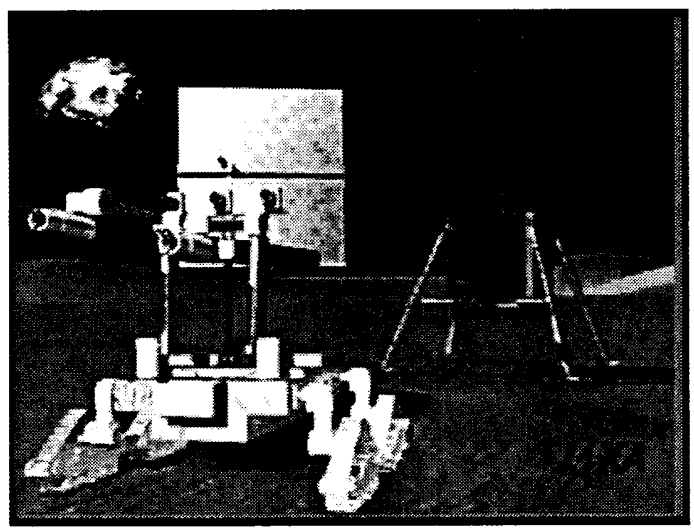

図 1 月面探査ローバの想像図

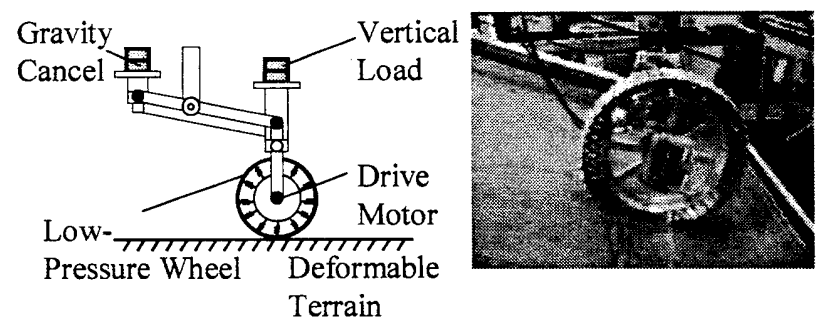

図 2 車輪実験設備 
表 1 試作車輪の主仕様

\begin{tabular}{c|cc}
\hline \hline Characteristics & Value & Unit \\
\hline Overall Diameter & 370.0 & $\mathrm{~mm}$ \\
Overall Width & 80.0 & $\mathrm{~mm}$ \\
Rim Diameter & 280.0 & $\mathrm{~mm}$ \\
Rim Width & 65.0 & $\mathrm{~mm}$ \\
Spring Constant & 0.726 & $\mathrm{~N} / \mathrm{mm}$ \\
Wheel Mass & 1.216 & $\mathrm{~kg}$ \\
\hline
\end{tabular}
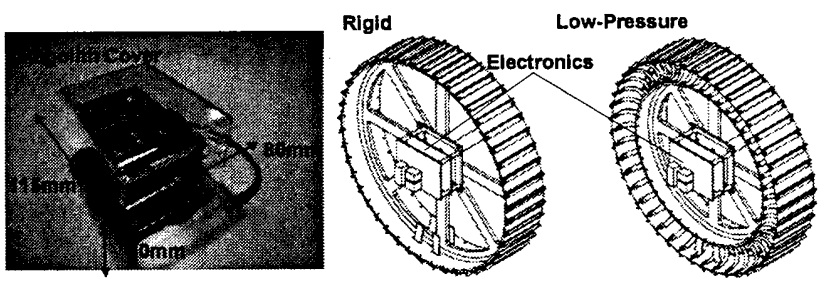

図 3 面圧計測車輪の概要

ばねは車輪横軸方向にそれぞれ $2 つ$ 固定され，車輪横ばね剛 性やステアリング特性を向上させている.

\section{2-3 面圧計測装置}

これまでの研究では接地面圧計測のために，剛性地盤上に 圧力センサを貼り付ける必要が有り，車輪はこの上を走行す る基礎的試験に留まっていた，そこで軟弱地盤上における接 地面圧計測のために, センサを車輪表面に貼り付けることと した. 次に，低圧車輪の接地面圧を計測するための増幅回路 を構成し，電源，無線モジュールを車輪に搭載可能な設計と して, 新規に開発を行った.

面圧計測車輪は走行路面との車輪接地面の閒にセンサを 持ち, 前節で検討を行った面圧計測装置を搭載する. 面圧計 測装置は転動中心における慣性モーメントを一定とするた めに, 車輪転動軸中心付近に設置する. 図 3 に面圧計測装置 と面圧計測車輪の外観を示す. 面圧計測車輪は低圧部の走行 性能評価のため，車輪径の等しい低圧車輪と剛性車輪で構成 する，センサの設置位置は面圧計測装置の $\mathrm{AD}$ 変換 $\mathrm{I} / \mathrm{F}$ から 8 点とし, 低圧車輪の表面ベルトにおける板ばね直下とそれ 以外の隙間直下を考慮して，車輪円周方向に 2 行，幅方向に 4 列とした。 サンプリング周波数はこれまでの計測実績と同 じ $20 \mathrm{~Hz}$ とした.

\section{3. テラメカニクスに基づく走行カ学}

\section{3-1 座標系}

低圧車輪における車輪座標系を図 4 に示す. 車輪の進行方 向を $x$, 車輪転動軸を $y$, 鉛直上向きを $z$ とする. 車輪の転 動速度を $\omega$, 車輪の並進方向の移動速度を $v_{x}$ とする $[8]$.

\section{3-2 低圧車輪の有効半径}

剛性車輪が軟弱地盤上を走行する際は, 車輪の半径は転動 や垂直荷重によって変化しない.このとき車輪の転動に伴う 有効半径は一定であるが, 軟弱地盤上を低圧車輪が走行する 場合は，接地面からの忘力で車輪が変形するため, 有効半径 を一定とすることが出来ない，車輪と地盤の両方が変形する ため，問題は複雑になる。

車輪は入射角 $\theta_{f}$ 之離脱角 $\theta_{r}$ の間でほほ線形な形状を取り, その他の部分では円弧形状となる．低圧車輪が剛性面上を走 行する際，車輪の有効半径 $R_{(\theta)}$ は以下のように表される[9]. ここで $R_{u}$ は車輪変形前の半径, $\zeta, \beta$ は車輪の剛性, 減衰 率，車輪形状，車輪転動速度に依存する係数であり，実験的 に得られる。

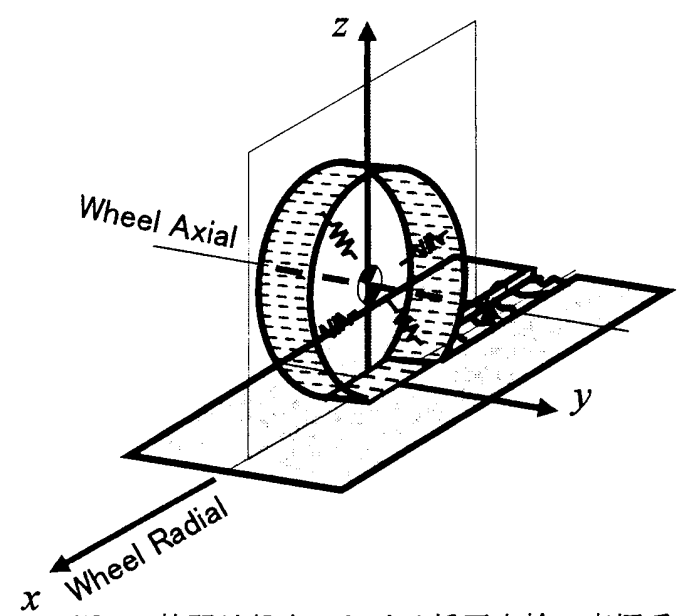

図 4 軟弱地盤上における低圧車輪の座標采

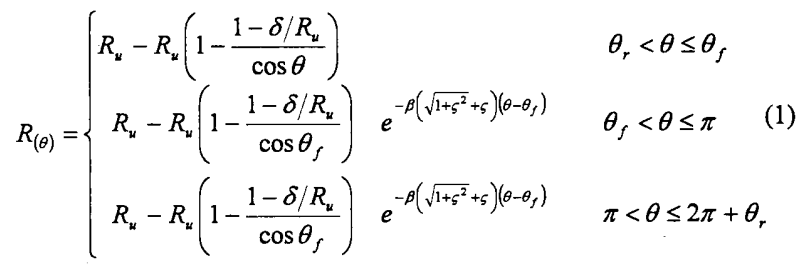

3-3 低圧車輪のすべり率

車輪のすべり率 $s$ は車両の移動に対して車輪が空転する割 合であり, 車両並進速度 $v_{x}$ と車輪回転速度 $\omega$ を用いて以下の ように定義される[10].

$$
s= \begin{cases}\frac{\left(r \omega-v_{x}\right)}{r \omega} & \left(r \omega>v_{x}: \text { 車輪駆動時 }\right) \\ \frac{\left(r \omega-v_{x}\right)}{v_{x}} & \left(r \omega<v_{x}: \text { 車輪制動時 }\right)\end{cases}
$$

\section{3-4 低圧車輪の垂直応力とせん断応力}

車輪に発生する力は車輪と土袞において生じる応力を車 輪接地面で積分することによって計算できる.この車輪接地 範囲は入射角之離脱角によって定義される。

軟弱地盤上を車輪が転動すると，図 5 に示すように車輪の 接地面における法線方向に垂直応力が生じる. 以下の表記に おいては, 垂直応力の最大值を発生する最大応力発生角であ る $\theta_{m}$ によって車輪前方と後方に分割して考える. また軟弱 地盤と低圧車輪は車輪半径が一定となる領域を挟んで3つの 接地面圧の定式が存在するため, 以下のように定義する.

$$
\sigma\left(R_{(\theta)}\right)=\left\{\begin{array}{l}
\sigma_{f}\left(R_{f}\right) \\
\sigma_{r}\left(R_{c}\right) \\
\sigma_{r}\left(R_{r}\right)
\end{array}\right.
$$

$\theta_{m}$ の定義方法はいくつかの報告例があるが，最も一般的 な以下のものを用いる.

$$
\theta_{m}=\left(a_{0}+a_{1} s\right)\left(\theta_{f}-\theta_{c}\right)+\theta_{c}
$$

$a_{0}, a_{1}$ は定数である.土壤における平板貫入試験の式によ

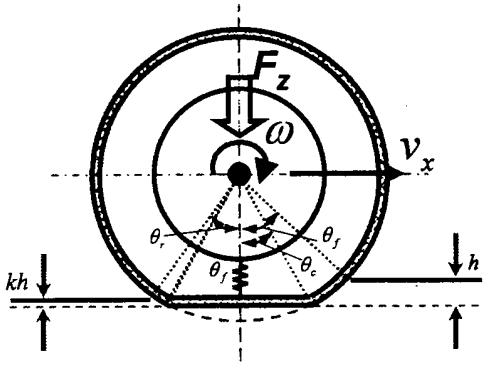

図 5 軟弱地盤上を走行する低圧車輪の定常状態 

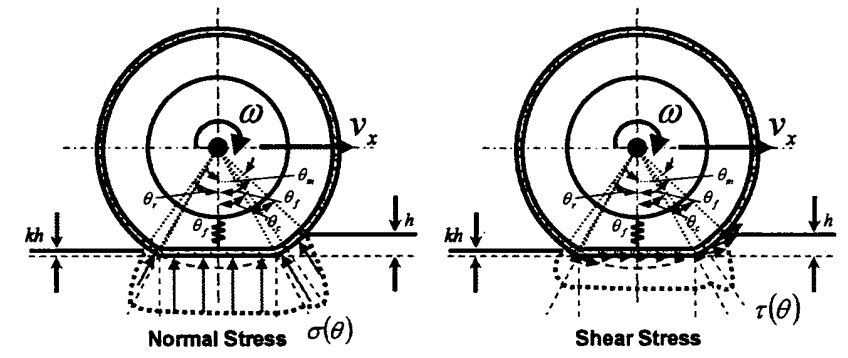

図 6 垂直応力とせん断応力分布

り垂直応力分布のモデル式は以下のようになる.

$$
\sigma\left(R_{(\theta)}\right)=\left\{\begin{array}{c}
\sigma_{f}\left(R_{f}\right)=\left(\frac{k_{c}}{b}+k_{\phi}\right)\left[R_{f(\theta)}\left(\cos \theta-\cos \theta_{f}\right)\right] \\
\sigma_{r}\left(R_{c}\right)=\left(\frac{k_{c}}{b}+k_{\phi}\right)\left[R_{c(\theta)}\left(\cos \left\{\theta_{f}-\frac{\theta-\theta_{r}}{\theta_{m}-\theta_{r}}\left(\theta_{f}-\theta_{m}\right)\right\}-\cos \theta_{f}\right)\right]^{n} \\
\sigma_{r}\left(R_{r}\right)=\left(\frac{k_{c}}{b}+k_{\phi}\right)\left[R_{r(\theta)}\left(\cos \left\{\theta_{f}-\frac{\theta-\theta_{r}}{\theta_{m}-\theta_{r}}\left(\theta_{f}-\theta_{m}\right)\right\}-\cos \theta_{f}\right)\right]^{n}
\end{array}\right.
$$

剛性車輪の軟弱地盤上におけるせん断時の応力-変位線曲 線は以下の式によって定義される[11]. ここで $\tau_{\max }$ は変位せん断応力曲線の最大值である.

$$
\begin{aligned}
& \tau_{\max }=c+\sigma \tan \phi \\
& \tau=\tau_{\max }\left[1-e^{-j / k}\right]
\end{aligned}
$$

$j$ は土壤の変形量 (せん断変位量),$k$ は変形係数で時定 数と走行する車輪の形状に依存する.また $c, \phi$ は土壃固有の 值であり、それぞれ土壤粘着力, 土袞内部摩擦角と呼ばれる. 式（5）によって垂直応力は算出されているので, 車輪座標 系における $x$ 方向のせん断応力 $\tau(\theta)$ は以下のように定義さ れる.

$$
\tau(\theta)=c+\sigma(\theta) \tan \phi\left[1-e^{-j(\theta) / k}\right]
$$

ここで、 $x$ 方向の土壤変形量 $j(\theta)$ の導出は, すべり速度 $v_{j}(\theta)$ をとに計算される. すべり速度は, 車輪円周方向速 度と車輪並進速度の円周接線方向速度の差として与えられ る.

$$
v_{j}(\theta)=r \omega-v \cos \theta=r \omega[1-(1-s) \cos \theta]
$$

上式から土壌変形量 $j(\theta)$ は以下のように表すことが出来 る.

$$
\begin{aligned}
j(\theta) & =\int_{b} v_{j}(\theta) d t=\int_{b \theta}^{\theta_{f}} r \omega[1-(1-s) \cos \theta] \frac{1}{\omega} d \theta \\
& =r\left[\theta_{f}-\theta-(1-s)\left(\sin \theta_{f}-\sin \theta\right)\right]
\end{aligned}
$$

低圧車輸の垂直応力とせん断応力分布を図 6 に示す.

\section{3-5 低圧車輪の駆動力}

前節における垂直応力とせん断応力を用いて, 車輪の入射 角から離脱角まで積分することにより車輪に生じる駆動力 を以下のように算出する.

$$
F_{x}=R(\theta) b \int_{\theta_{r}}^{\theta_{f}}\{\tau(\theta) \cos \theta-\sigma(\theta) \sin \theta\} d \theta
$$

低圧車輪の駆動力の算出における幾何的関係を図 7に示す.

\section{4. 㳄影地盘上における走行实的}

\section{4-1 すべり率の算出}

走行実験および解析における実験条件を表 2 示す. 走行時 のテレメトリ履歴から剛性, 低圧の両車輸ともほとんどすべ りを生じていないことが分かる.これは, 過去の実験結果と も類似しており, 試作車輪の半径が $0.185[\mathrm{~m}]$ と大きいことか

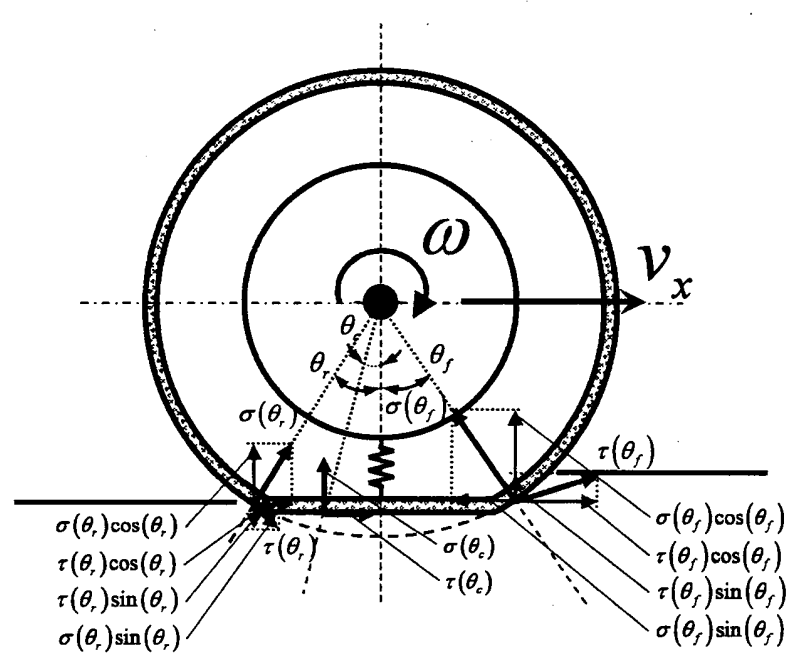

図 7 駆動力と垂直抗力の関係

表 2 走行実験および理論計算の条件

\begin{tabular}{c|cc}
\hline \hline Characteristics & Value & Unit \\
\hline Wheel Type & Rigid/Low & - \\
Velocity & $20 / 50$ & $\mathrm{~mm} / \mathrm{sec}$ \\
Load & 20 & $\mathrm{~N}$ \\
Terrain & Regolith & - \\
Slope Angle & Stimulant & $\mathrm{deg}$ \\
\hline \hline
\end{tabular}

ら，この車輪では剛性，低圧に限らずすべり率が小さいとい える.

\section{4-2 垂直忘力の比較検討}

垂直応力の表示に際して, 車輪接地面の表面における座標 系を定義する.この座標系は車輪表面から鉛直下向き方向に 圧力を，また車輪中心から鉛直下向きに横軸の原点をとり， 車輪の回転角度を表している. 接地面圧力は単位面積あたり の力で表す. 低圧車輪では車輪が地盤への沈下に伴って変形 をおこすため, この変形後の車輪表面からの垂直応力と定義 する.

面圧計測装置を用いて計測を行った結果と, 第 3 章におい て示した低圧車輪のテラメカニクス走行力学モデルを用い てて理論計算を行った結果を図 8 に示す. 接地面圧力の目安と して，座標軸の 1 枡あたりは $10[\mathrm{kPa}$ の接地圧力である.こ れまでに月面上を走行するための最適な接地面圧は 10 [kPa] 以下が望ましい，剛性車輪では，低速域における計測で 10 $[\mathrm{kPa}$ を超過した接地面圧力となるものの，それ例外の計測条 件では接地面圧が 10 [kPa]以内に収まる結果となっている.

理論計算において，算出に用いた定数の值を表 3 に示す.

低圧車輪では, 入射角, 離脱角, 最大角の定義から車輪形 状が一定となる前方の角度と入射角の間で最大圧力点を持 つ. また, 車輪径が一定となる領域に関しては, 離脱角に近 づくに従って接地面圧が減少する領域に含まれる。理論計算 では車輪の接地面積とその接地面圧に関して, 剛性車輪では 面積が狭く面圧は大きくなるのに対して，低圧車輪では接地 面積が広く，また面圧は小さくなっていることがわかる．ま た，すべりを生じていないことから車輪の転動速度が変更と なっても沈下量が変化せず, 従って接地面圧の圧力分布も速 度により変化しない結果となった。

計測では事前に実施した剛性地盤上での基礎計測と比較 して, 軟弱地盤では接地面積が広く, 接地面圧が小さくなる ことが分かった。また，軟弱地盤上での計測では剛性車輪と 比較して低圧車輪の方が, 接地面積が広く, 接地面圧が小さ 

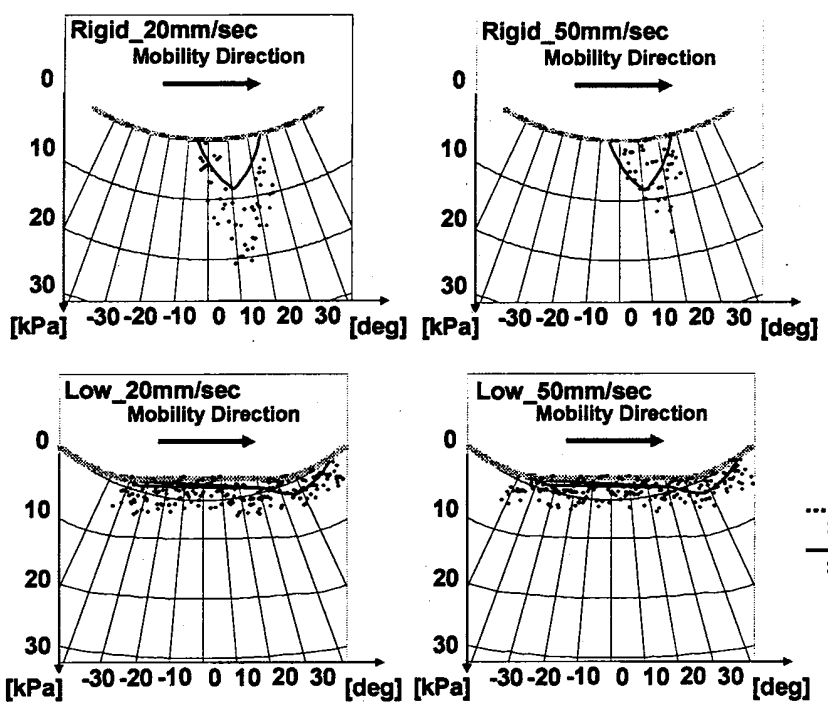

図 8 垂直応力の理論値と計測値

表 3 理論計算のパラメタ

\begin{tabular}{c|cc}
\hline \hline Characteristics & Value & Unit \\
\hline$a_{0}$ & 0.4 & - \\
$a_{1}$ & 0.15 & - \\
$b$ & 0.08 & $m m$ \\
$c_{0}$ & 0.015 & - \\
$k_{c}$ & $1.37 \times 10^{3}$ & $N / m^{n+1}$ \\
$k_{c \phi}$ & $8.14 \times 10^{5}$ & $N / m^{n+2}$ \\
$n$ & 1.0 & - \\
$R_{u}$ & 0.185 & $m$ \\
$s$ & $0.0-1.0$ & - \\
$W$ & 20 & $N$ \\
$\zeta$ & 6.75 & \\
$\beta$ & 0.1175 & \\
\hline \hline
\end{tabular}

くなることが分かった．これは理論計算と同様に，低圧車輪 では車輪自体が変形することにより車輪の沈下を考虑して, 垂直応力を生じさせている車輪の垂直荷重を軟弱地盤が広 く受け止めることと一致する. また, 理論値に比べ計測値の 接地面圧は一様に大きい值となっているが, 剛性, 低圧とも 車輪の入射角之離脱角の間に最大応力角を持ち, その前後で なだらかな分布をとる傾向は一致している．また車輪の転動 速度が大きくなると，接地面圧力分布が小さくなる結果とな った.これは理論計算の結果とは必ずしも一致しないが, こ れまでの他計測装置を用いた実験でも確認されており，すべ りを生じていなくても速度と接地面圧力が反比例すること が現象として予想される.

また解析と計測から得られた車輸のけん引力を図9に示す. 剛性車輪ではすべり率が 0 の場合, 地盤の変形量が小さいた めせん断応力よりも垂直応力が大きいことが予想される.そ のため, せん断応力と垂直応力の水平方向成分を積分して求 める駆動力は負となる。しかし低圧車輸では, 地盤との接地 面にでは車輪変形により垂直応力の水平成分は 0 となる. そ のためせん断力は小さいながらも方範囲にわたる接地面積 により穔分され，駆動力はすべり率が 0 でも正となる. 㓮性・ 低圧車輪ともすべり率の増加に伴って駆動力が増加するが, 全ての範囲において低圧車輪の駆動力が剛性車輪のそれよ りも大きいことが分かる．また，すべり率が小さい条件での 計測值を理論值と比較してみると低圧車輪が剛性車輪より

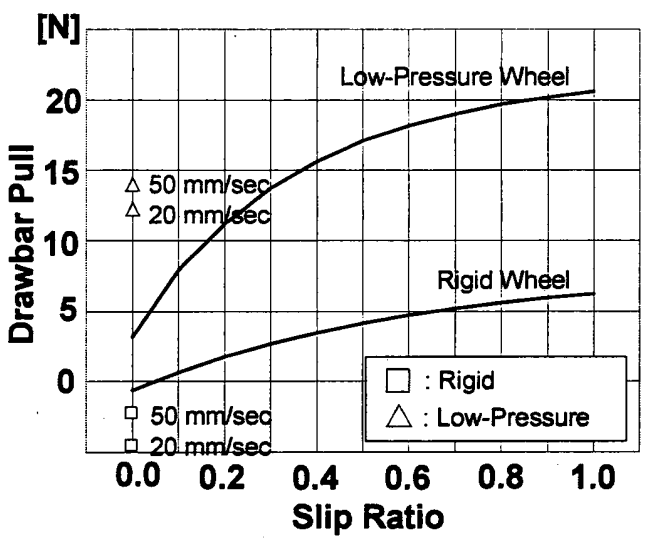

図 9 けん引力の理論値と計測値

も大きい駆動力を持つことが分かる.

\section{5. 结吾}

本研究では, 低圧車輸の走行性能の評価とその改善を目指 し，軟弱地盤上における垂直忘力の計測，および駆動力の評 価を行った. その結果以下の成果・知見を得た. 今後の課題 と合わせて記述する.

（1）計測された垂直応力と理論計算值を比較した結果, 低圧 車輪は剛性車輪と比べて, 接地面圧力の最大值が小さく, また広範囲に渡って地盤との垂直応力が生じているこ とが分かった。

(2) 計測と解析から得られた垂直応力からせん断応力を算 出し, 車輪の駆動力を求めた. その結果, 低圧車輪は剛 性車輪と比べて, 全てのすべり率の範囲で駆動力が大き く, 剛性車輪よりも高い走行性能を有することが分かっ た.

（3）今後は車輪転動の複数環境（キャンバ角，スリップ角， 斜面走行）での計測を行い，低圧車輪の走行性能の評価 を引き続き実施すると共に，低圧車輪のコーナリングや 制駆動特性といった実運用に即した車輪特性や動的走 行性能評価を実施する.

\section{6. 劣文模}

[1] 橋本, 田中, 星野, 大柣:月着陸探査ミッション SELENE-2, 第 54 回宇宙科学技術連合講演会, 2010

[2] 西田, 星野, 松本:JAXA の月探査技術の研究開発状況,

第 53 回宇宙科学技術連合講演会, 2009

[3] 若林, 佐藤, 松本:クローラ型月面走行系の設計と走行評

価，テラメカニックス第 26 号，2006

[4] 吉村, 山川, 渡辺:砂地走行用タイヤモデルの構築, テラ メカニックス第 28 号, 2008

[5] 若林, 河野, 西田:月面低圧走行系の検討, テラメカニッ クス第 29 号, 2009

[6] 成田, 大槻, 若林, 西田:軟弱地盤上における低圧車輪の 走行性能評価, 第 19 回スペースエンジニアリンクコンファ レンス, 2011

[7] 成田, 大柣, 若林, 西田:非線形特性を有する月探査ロー

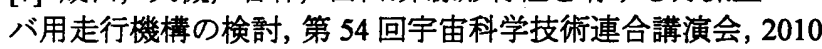
[8] 自動車技術会:自動車技術ハンドブック 基礎・理論編， 自動車技術会, 2004

[9] Chan, B. J., and Sandu, C., Off-Road Vehicle Mobility and Energy Efficiency Prediction, Proceeding of $9^{\text {th }}$ APISTVS International Conference, 2010

[10] G Bekker., Theory of Land Locomotion, The University of Michigan Press, 1956.

[11] Janosi, Z., and Hanamoto, B., The analytical determination drawbar pull as a function of slip for tracked vehicle, Proceeding of $1^{\text {st }}$ ISTVS International Conference, 1961. 